\title{
EWANGELIKALNE CHRZEŚCIJAŃSTWO WOBEC JUDAIZMU
}

\begin{abstract}
Apostoł Paweł, traktując w Liście do Rzymian o włączeniu nie-Żydów w zbawczy plan Boży w Chrystusie, w obliczu faktu, że kerygmat chrystologiczny nie stał się częścią żydowskiej wiary, musiał zająć się teologicznym miejscem narodu wybranego. Apostoł świadomy był, że obietnice Boże są nieodwołalne (Rz 3,1-3), w związku z czym podjął się kilku prób wytłumaczenia Bożej wierności obietnicom danym Izraelowi (Rz 9-11). Paweł nie dał konkretnej odpowiedzi, lecz zakończył swoje rozważania przekonaniem, że w czasach ostatecznych „cały Izrael” będzie zbawiony (Rz 11,26), a zamiast wyjaśnienia, w jaki sposób się to odbędzie, wygłosił wspaniałą doksologię za pomocą apokaliptycznego hymnu o niezgłębionej mądrości Boga (Rz 11,33-36). W ten sposób apostoł pokazał, że istnieje w Kościele miejsce do uprawiania teologii Izraela.

Temat Izraela oraz przymierza, które zawarł z nim Bóg, jest mocno obecny teologii ewangelikalnej. Pod nazwą „,chrześcijaństwo ewangelikalne”, ewentualnie ,protestantyzm ewangelikalny” należy rozumieć ten nurt w obrębie protestanckiego chrześcijaństwa, dla którego - według definicji A. McGratha przytaczanej przez Tadeusza J. Zielińskiego, autora wyjątkowej monografii poświęconej protestantyzmowi ewangelikalnemu - konstytutywne byłyby następujące cechy: ${ }^{1}$ skupienie się, zarówno pobożnościowe jak i teologiczne, na osobie Jezusa Chrystusa, zwłaszcza na Jego śmierci na krzyżu;
\end{abstract}

1 Bardzo podobnie charakteryzują ewangelikalizm inni badacze cytowani przez T. J. Zielińskiego; zob. T. J. Z i e 1 i ń s k i, Protestantyzm ewangelikalny. Studium specyfiki religijnej, Warszawa 2013, s. 16. Sam autor dokonał podziału części systematycznej swojej pracy zgodnie z głównymi cechami ewangelikalizmu, na części zatytułowane: Konwertyzm, Biblizm i Konwentyklizm. 
uznanie Pisma za ostateczny autorytet w sprawach duchowości, doktryny i etyki; nacisk na nawrócenie lub „nowe narodzenie” jako przemieniające życie doświadczenie religijne; skupienie się na dzieleniu swą wiarą, szczególnie przez ewangelizację.

Chociaż pewne cechy ewangelikalne znajdujemy w Kościołach nieprotestanckich, to jednak pod względem zarówno doktryny jak i praktyki ewangelikalizm jest nurtem protestanckim. Jak zauważa T. J. Zieliński, niesłuszne jest natomiast przeciwstawianie sobie określeń „ewangelikalny” i „ewangelicki”, ponieważ zachodzą one na siebie. ${ }^{2}$ Tak więc istnieją Kościoły protestanckie, czyli ewangelickie, które w całości będą mieścić się w nurcie ewangelikalnym, jak i Kościoły protestanckie, które będą ewangelikalne tylko w części. Do Kościołów o charakterze ewangelikalnym w Polsce należeć będą np. Kościół Ewangelicznych Chrześcijan i Kościół Zielonoświątkowy, zaś w takich Kościołach jak Kościół Ewangelicko-Augsburski lub Kościół Ewangelicko-Reformowany będą istniały ugrupowania i ruchy o charakterze ewangelikalnym. Początków ewangelikalizmu należy najprawdopodobniej doszukiwać się w pierwszej połowie XVIII w. i wiązać jego powstanie $z$ działalnością Johna Wesleya. ${ }^{3}$

Nurt ewangelikalny chrześcijaństwa cechuje przekonanie o konieczności „nowego narodzenia” do życia z Bogiem, które jest życiem wiecznym w Bożej rzeczywistości zbawczej. $Z$ tego powodu chrześcijanie ewangelikalni prowadzili działalność misyjną wśród przedstawicieli innych religii, w tym wśród Żydów. W XIX w. powstawało wiele towarzystw poświęconych misji wśród Żydów. ${ }^{4}$ Ich działania

\section{Tami̇e, s. 22. \\ Tamże, s. 41.}

4 Należały do nich np. London Society for Promoting Christianity amongst the Jews (zał. w 1809 r.), którego nazwa zmieniona została na Church Mission to Jews, British Society for Promoting Christianity amongst the Jews (zał. w 1842 r.), American Society for Meliorating the Condition of the Jews (zał. w 1820 r.), Hebrew Christian Alliance of Great Britain (zał. w 1893 r.), Barbican Mission to the Jews (zał. w 1889 r.), Hebrew Christian Testimony to Israel (zał. w 1893 r.), American Board of Missions to the Jews (zał. w 1894 r.); tamże, s. 279. Na ziemiach Polskich anglikańskie misje wśród Żydów, zwłaszcza London Society for Promoting 
odróżniały się jednak tym, że nie uznawano przymusu w prowadzeniu misji. Chrześcijanie ewangelikalni odczuwali pewnego rodzaju wspólnotę z Żydami, ponieważ także oni nierzadko doświadczali prześladowań i dyskryminacji. Dlatego też niejednokrotnie występowali na rzecz równouprawnienia ludności żydowskiej. ${ }^{5}$ Do samych Żydów żywiono pozytywny stosunek, ale oczywiście nie oznacza to, że środowiska ewangelikalne w przeszłości wolne były, czy nawet obecnie są wolne, od antysemityzmu i antyjudaizmu. Omówione zostaną raczej poglądy reprezentatywnych dla większej części chrześcijan ewangelikalnych.

Współcześnie stosunek do judaizmu środowisk ewangelikalnych charakteryzowany jest przez dwie podstawowe cechy. Po pierwsze, powszechne jest przekonanie o trwającym wciąż wybraniu Izraela oraz nadzieja na odegranie przez Izrael ważnej roli w czasach ostatecznych. $Z$ jednej strony przekonanie to prowadzi do szczerego, chociaż często powierzchownego, zainteresowania judaizmem, do postulatu powrotu chrześcijaństwa do żydowskich korzeni, z drugiej strony zaś skutkuje pewnymi napięciami w teologii ewangelikalnej, które nie zostały jeszcze przezwyciężone. Po drugie, ewangelikalizm w dalszym ciągu prowadzi misję ewangelizacyjną wśród Żydów, z tym że ma ona inny charakter niż wcześniej. Niniejszy przyczynek będzie omawiał stosunek chrześcijan ewangelikalnych do judaizmu, biorąc pod uwagę właśnie dwa wyżej wspomniane aspekty.

Zmiana stosunku chrześcijaństwa do judaizmu i Żydów nastąpiła po II wojnie światowej. Pierwsze deklaracje Kościołów ewangelickich były wyznaniami winy. ${ }^{6}$ Następnie za wypowiedziami apostoła Pawła

Christianity amongst the Jews prowadziły działalność od 1818 r. W 1866 r. W Wilnie rozpoczęło działalność British Society for Promoting Christianity Amongst the Jews. W Polsce działały także inne organizacje ewangelizujące Żydów np. Misja Mildmajska czy Misja Barbikańska; zob. T. W i ś n i e w s k i, Nawracanie Żydów na ziemiach polskich. Misja Barbikańska w Białymstoku, Łódź 2013, s. 44-80.

5 T. J. Z i el i ń s k i, Protestantyzm ewangelikalny, s. 279.

6 Wymienić tu można Stuttgarckie Wyznanie Winy z 1945 r., które jeszcze nie wzmiankuje Żydów wprost, ale „wiele narodów i krajów”; zob. Stuttgatckie Wyznanie Winy, Portal luteranie.pl, dostępny w Internecie: http://old.luteranie.pl/ 
z Listu do Rzymian przyjmowano, że Izrael nie został przez Boga odrzucony i że Boże obietnice doń skierowane są wciąż aktualne. Podobny proces występował w przypadku nurtu ewangelikalnego. W środowiskach tych najczęściej odrzucana jest teologia zastąpienia, którą postrzega się jako główną przyczynę chrześcijańskiego antyjudaizmu oraz aktywnej nienawiści do judaizmu i Żydów. Powszechnie przyjmuje się, że Izrael jest narodem wybranym, akceptuje się przekonanie wyrażone w Liście do Rzymian, że eschaton ujawni pełnię chwały Izraela (Rz 11,12), jednak teologowie ewangelikalni nie ustosunkowują się najczęściej do kwestii soteriologii, a konkretnie do zagadnienia, czy w religii żydowskiej istnieje potencjał zbawczy dla pojedynczego wyznawcy. Przekonanie o trwającym wybraniu Izraela wywołuje pewne napięcie, ponieważ w ewangelikalnej tradycji teologicznej do zbawienia konieczne jest nawrócenie i wiara w zbawczą ofiarę Chrystusa. W publikacjach ewangelikalnych poświęconych judaizmowi próżno szukać tego rodzaju stwierdzeń teologicznych jak w chrześcijańskiej deklaracji Święty obowiązek, w której czytamy, że zarówno Żydzi jak i chrześcijanie „niosą świadectwo odpowiednich dla siebie zbawczych dróg Boga". ${ }^{8} \mathrm{~W}$ następnym zdaniu autorzy

pl/?D=766 (dostęp: 4 VI 2015); Wort zur Judenfrage z 8 IV 1948 r. ogłoszony przez Bruderrat Kościoła Ewangelickiego (EKD) w Niemczech, czy też deklaracja Wort zur Judenfrage ogłoszona przez Synod Kościoła Ewangelickiego w Niemczech w kwietniu 1950 r. Zob. M. B o c k, Ihr aber, wer sagt ihr, daß ich się $(M k 8,29)$. Christologische Fragestellungen im christlich-jüdischen Gespräch nach 1945, Frankfurt am Main 1998, s. 41-49.

7 Jako przykład służyć może pozycja M. B ol e n d e r, Kiedy krzyż stał się mieczem. Pochodzenie i konsekwencje teologii zastapienia, Oświęcim 2011. Książka zawiera przykłady teologicznych stwierdzeń będących odzwierciedleniem tejże teologii, wypowiadanych przez Ojców Kościoła i reformatorów, przedstawia przykłady prześladowań Żydów motywowanych religijnie, podkreśla trwające wybranie Izraela oraz kilkakrotnie wzywa chrześcijan do pokory słowami Listu do Rzymian 11,20: „nie wzbijaj się w pychę, ale się strzeż”.

8 Angielski tekst deklaracji dostępny na stronie internetowej: https://www. bc.edu/content/dam/files/research_sites/cjl/sites/partners/csg/Sacred_Obligation. htm (dostęp: 4 VI 2015); tłum. pol.: http://religie.wiara.pl/doc/471918.Dialog-chrzescijanskozydowski-Swiety-obowiazek-przemyslec-na, (dostęp:4 VI 2015). 
deklaracji stwierdzają, że ,ani jedni ani drudzy nie mogą zasadnie twierdzić, że posiedli całkowitą lub wyłączną znajomość Boga". ${ }^{9}$ Teologowie ewangelikalni nie wzywają do redefinicji soteriologii, jak to występuje we wspomnianej deklaracji chrześcijańskich uczonych. ${ }^{10}$ Teologicznie wymowne byłoby stwierdzenie chrześcijan ewangelikalnych o tajemnicy i niewiedzy, zamiast tego najczęściej, chociaż nie zawsze, spotykamy w tej kwestii milczenie. Możliwe, że za owym milczeniem stoi obawa podważenia wyjątkowości krzyża Chrystusa, chociaż oczywiście przyjęcie, że przymierze Boga z Izraelem może trwać bez możliwości zbawczej dla jego ludzkich uczestników, byłoby czymś kuriozalnym. Taką pozycję jednoznacznie zajmuje jeden z głównych teologów nurtu Żydów mesjańskich David H. Stern, który rezygnację z ewangelizacji Żydów, a nawet jej zaniedbywanie nazywa najgorszym aktem antysemityzmu. ${ }^{11}$ Pisze on: „Bez Jeszuy naród żydowski, tak jak poganie, przeznaczony jest na wieczną zagładę (...) bez Jeszuy naród żydowski (i inne narody), pojedynczo i zbiorowo, nie mają żadnej nadziei". ${ }^{12}$ Jak w większości chrześcijanie ewangelikalni milczą na temat zbawczego potencjału w judaizmie, tak zdecydowanie sprzeciwiają się koncepcji dwóch przymierzy. ${ }^{13}$ Zapewne w tym przypadku również należy brać pod uwagę obawę przed umniejszeniem drogi zbawienia w Chrystusie. Tak więc podejście chrześcijaństwa ewangelikalnego do judaizmu jest niespójne pod względem teologicznym. Chrześcijanie ewangelikalni deklarują

9 Święty Obowiązek, http://religie.wiara.pl/doc/471918.Dialog-chrzescijanskozydowski-Swiety-obowiazek-przemyslec-na (dostęp: 4 VI 2015).

10 Punkt 6 deklaracji zawiera słowa: „Po uświadomieniu sobie w ostatnich czasach tego, że przymierze Boga z Żydami jest wieczne, chrześcijanie obecnie są w stanie uznać działanie odkupieńczej mocy Boga w tradycji żydowskiej. Skoro Żydzi, nie podzielając naszej wiary w Chrystusa, pozostają w zbawczym przymierzu z Bogiem, chrześcijanie potrzebują nowych sposobów rozumienia powszechnego znaczenia Chrystusa"; tamże.

11 D. H. S t e r n, Przywracanie żydowskiego charakteru Ewangelii. Poselstwo dla chrześcijan, Wydawnictwo Dabar (b. m. r. w.) s. 76.

12 Tamże.

13 Tamże. 
sympatię wobec Izraela i Żydów, odrzucają teologię zastąpienia, przyznają trwanie wybraństwa i przymierza Boga z Izraelem, jednakże nie są w stanie owego przymierza dokładniej teologicznie opisać ani wyjaśnić na czym owo wybranie miałoby polegać w rzeczywistości Nowego Przymierza. Jeżeli chodzi o potencjał zbawczy judaizmu, to spotykamy się z milczeniem w tej kwestii, ewentualnie ze stwierdzeniami o konieczności uwierzenia w Chrystusa. O wiele spójniejsze jest przekonanie o dwóch drogach zbawienia, które zdaje się być obecne w deklaracji Święty Obowiązek, czy też koncepcja włączenia przez Chrystusa nie-Żydów w rzeczywistość Bożą Izraela. ${ }^{14}$ Podobnie spójny i zgodny z soteriologią i eklezjologią rzymskokatolicką jest pogląd wyrażony w deklaracji Dominus Iesus, która nie odmawia możliwości osiągnięcia zbawienia wyznawcom judaizmu i innych religii niechrześcijańskich, ale podstawę do owego zbawczego potencjału widzi w mistycznej łączności z Kościołem katolickim, przez którą udzielane jest Chrystusowe zbawienie. ${ }^{15}$

Misje ewangelikalne pośród Żydów są obecnie prowadzone jako działalność tzw. judaizmu mesjańskiego. Organizacje Żydów mesjańskich są w prostej linii kontynuacją dziewiętnastowiecznych

14 Oba poglądy, ich strony pozytywne, ale i teologiczne wątpliwości, do których takie stanowiska prowadzą omawia dokument pt. Kościót i Izrael przyjęty w 1999 r. przez Kościoły zrzeszone w Leuenberskiej Wspólnocie Kościołów. Kościół i Izrael, http://www.prchiz.pl/prchizwypprotlpopup.html\#_Toc478304190, (dostęp: 4 VI 2015).

15 Deklaracja zawiera słowa: „Dla tych, którzy nie są w sposób formalny i widzialny członkami Kościoła, «Chrystusowe zbawienie dostępne jest mocą łaski, która, choć ma tajemniczy związek z Kościołem, nie wprowadza ich do niego formalnie, ale oświeca ich w sposób odpowiedni do ich sytuacji wewnętrznej i środowiskowej. Łaska ta pochodzi od Chrystusa, jest owocem Jego ofiary i zostaje udzielana przez Ducha Świętego». Ma ona związek z Kościołem, który «swój początek bierze wedle planu Ojca z posłania (ex missione) Syna i z posłania Ducha Świętego"; Kongrega c j a Nauk i Wi ary, Deklaracja „Dominus Iesus" o jedyności i powszechności zbawczej Jezusa Chrystusa i Kościoła, http:// www.opoka.org.pl/biblioteka/W/WR/kongregacje/kdwiary/dominus_iesus.html (dostęp: 4 VI 2015). 
towarzystw misyjnych. ${ }^{16}$ Misja wśród Żydów prowadzona jest w ten sposób, że chrześcijaństwo przedstawiane jest jako pewnego rodzaju dopełnienie judaizmu. Osoby nawrócone na religię chrześcijańską określają się mianem Żydów mesjańskich, zachowują niektóre obrzędy typowe dla judaizmu, elementy żydowskiej modlitwy, ewentualnie dopasowują żydowską liturgię do chrześcijańskich poglądów. ${ }^{17}$ Bywa, że swoich duchownych określają mianem rabinów, a swoje społeczności nazywają synagogami. ${ }^{18}$ Charakterystyczne jest dla nich również korzystanie z artefaktów judaizmu - tałesów ozdobionych imieniem Jezusa, mezuz przyozdobionych znakiem ryby, symbolem chrześcijaństwa. Zapewne w celu prowadzenia misji posługują się oni hebrajskimi imionami Jezusa i apostołów. I tak w publikacjach Żydów mesjańskich pojawiają się przykładowo Jeszua, Jochanan, Szaul i List do Żydów Mesjanistycznych, w miejsce odpowiednio Jezusa, Jana, Pawła i Listu do Hebrajczyków. ${ }^{19}$

Czy można mówić o jakichkolwiek teologicznych wyróżnikach nurtu Żydów mesjańskich, które wydzielałyby ich poza chrześcijaństwo ewangelikalne? Poza liturgią i praktyką można zwrócić uwagę jedynie na pewne teologiczne akcenty. Z pewnością Żydzi mesjańscy dostrzegają to, co i współcześni egzegeci Nowego Testamentu, a mianowicie żydowskość pierwotnego chrześcijaństwa i, co za tym

16 Organizacje tzw. Żydów mesjańskich mają charakter misyjny i nierzadko są w prostej linii kontynuatorami dziewiętnastowiecznych, protestanckich, głównie ewangelikalnych, towarzystw misyjnych, które stawiały sobie za cel nawrócenie Żydów na chrześcijaństwo; np. American Board of Missions to the Jews stało się później Chosen People Ministries. Z tej pierwszej organizacji wywodzi się również założyciel Jews for Jesus. Messianic. Jewish Alliance of America miał niegdyś w swojej nazwie wprost słowo „Christian”, ponieważ nazywał się Hebrew Christian Alliance of America; zob. T. J. Z i e 1 i ń s k i, Protestantyzm ewangelikalny, s. 279n.

17 Zob. np. chrześcijański sidur: HaSiddur. The Messianic Prayer Book, dostępny w Internecie: http://www.shiloach.nl/upload/Ha\%20Siddur.pdf(dostęp: 4 VI 2015).

18 Ma to miejsce np. w przypadku organizacji International Aliance of Messianic Congregations and Synagogues; zob. terminologię stosowaną na stronie internetowej Aliansu: www.iamcs.org.

19 Taka terminologia używana jest np. w: H. D. S t e r n, Komentarz żydowski do Nowego Testamentu, Warszawa 2004. 
idzie, konieczność czytania tekstów Nowego Testamentu przez pryzmat Starego Testamentu i tekstów żydowskich Drugiej Świątyni. ${ }^{20}$ Charakterystyczne jest dla owego nurtu także przekonanie o dosłownej realizacji obietnic ziemi i królestwa Izraela, które ma zostać Izraelowi przywrócone. ${ }^{21} \mathrm{~W}$ Chrystusie obietnice te znajdują nie tyle swoją realizację, ile potwierdzenie. ${ }^{22}$ Równie znamienne dla Żydów mesjańskich jest usilne staranie pokazania na tekstach Starego Testamentu, mesjańskiej i boskiej godności Jezusa z Nazaretu. ${ }^{23}$ David H. Stern stoi na stanowisku, że Tora, która faktycznie jest jednym z ważniejszych pojęć teologicznych Nowego Testamentu, również obowiązuje w rzeczywistości Nowego Przymierza. ${ }^{24} \mathrm{~W}$ tłumaczeniu Nowego Testamentu autorstwa D. H. Sterna Pawłowa krytyka Prawa zostaje potraktowana jako odnosząca się nie do Tory jako takiej w życiu człowieka, ale do jej niewłaściwego wykorzystania. I tak, przykładowo, wyrażenie ,pod Prawem” oddawane jest przez „poddany systemowi zrodzonemu z wypaczenia Tory w legalizm”, a „uczynki Prawa” jako „legalistyczne przestrzeganie przykazań Tory". ${ }^{25}$ Teolog ten stoi na stanowisku, wedle którego również przymierze Nowego Testamentu zostało nadane jako Tora. ${ }^{26}$ David H. Stern dokonuje istniejącego również w judaizmie rabinicznym rozróżnienia między przykazaniami obowiązującymi Żydów oraz

20 Tamże, s. XIII-XIV.

${ }_{21}$ D. H. S t e r n, Przywracanie żydowskiego charakteru Ewangelii, s. 46-51.

22 Tamże, s. 46.

23 Tego rodzaju usiłowanie obecne jest publikacjach autorów związanych z ruchem Żydów mesjańskich. Znajduje się ono zarówno w cytowanej książce D. H. Sterna, w pozycji: A. F r u c h t e n b a u m, Jezus byt Żydem, Warszawa 2010; R. Fr y d l a n d, Co rabini wiedza o mesjaszu? Studium oparte na genealogii i proroctwach biblijnych, Kraków 1997. W komentarzu D. H. Sterna znajduje się specjalny wykaz starotestamentowych proroctw, które miały wypełnić się w Chrystusie; zob. te n ż e, Komentarz żydowski do Nowego Testamentu, s. XXIX-XXX.

24 Te n ż e, Przywracanie żydowskiego charakteru Ewangelii, s. 58-60.

25 Tamże, s. 54-56; t e n ż e, Komentarz żydowski do Nowego Testamentu, s. XXVII.

${ }_{26}$ Te n ż e, Przywracanie żydowskiego charakteru Ewangelii, s. 57-58. 
nie-Żydów. ${ }^{27}$ Przykazania, które miałyby obowiązywać nie-Żydów to, przykładowo, decyzja podjęta przez Sobór Jerozolimski (Dz 15), wedle której „,chrześcijanie z pogan mieliby się wstrzymywać od pokarmów ofiarowanych bożkom, od nierządu, od tego co uduszone i od krwi", czy też kwestie posłuszeństwa władzy świeckiej w Rz 13,1-7 i Dz 5,29. ${ }^{28}$ Przykazania odnoszące się do Żydów wierzących w Chrystusa autor określa mianem halachot Nowego Przymierza. Są to te sądy teologiczne, które wypowiedziane zostały przez Jezusa lub autorów pism Nowego Testamentu w sposób przypominający podejmowanie rabinicznych halachicznych rozstrzygnięć. Do owych halachot miałyby należeć m.in. pierwszeństwo micwy uzdrawiania nad micwą powstrzymywania się od pracy w Szabat (J 7,22-23), priorytet społeczności w Mesjaszu nad koszernością pokarmów (Ga 2,11-14). Pod koniec swoich rozważań D. H. Stern postuluje halachiczne opracowanie Tory opartej także na Nowym Testamencie, przeznaczonej zarówno dla Żydów jak i nie-Żydów. Jakkolwiek teologiczny temat Prawa był zaniedbywany w teologii zwłaszcza Starego Testamentu, to podejście D. H. Sterna do tematu Prawa jest kontrowersyjne. Jaką postać miałaby mieć proponowana przez Sterna Tora? Czy chodziłoby o próbę teologicznego wyłożenia Pięcioksięgu wraz z jego wykładem i normami prawnymi znajdującymi się w Nowym Testamencie? Czy należałoby wprowadzić ewentualnie zmodyfikować interpretacje przykazań wprowadzanych przez rabinów w okresie starożytnym i później? A może należałoby zawęzić ją do rozstrzygnięć, które istniały w czasie współczesnym Jezusowi, wszak istniała już wówczas koncepcja Tory ustnej? Teolog nie wypowiada się na temat przykazań dotyczących kultu ofiarniczego. Czy staje on na pozycji judaizmu rabinicznego, wedle którego modlitwa zastępuje ofiarę? Hasło Davida Sterna, aczkolwiek efektowne, zdaje się problematyczne, jak zazwy-

$27 \mathrm{~W}$ judaizmie rabinicznym przykazania adresowane do nie-Żydów ujęte zostały przez Majmonidesa jako siedem przykazań noachickich; zob. P. M a j d a n i k, Tora dla narodów świata, Prawa noachickie w ujęciu Majmonidesa, Warszawa-Toruń 2015 (zwł. podrozdział o prawach noachickich przed Majmonidesem, s. 23-28).

28 D. H. S t e r n, Przywracanie żydowskiego charakteru Ewangelii, s. 64-67. 
czaj bywa to z usilną próbą powiązania ze sobą odrębnych tradycji religijnych. Do tego metoda czytania tekstów Nowego Testamentu Sterna zdaje się nie uwzględniać kontekstu, w jakim chrześcijaństwo rozwijało się w I w. n.e. Wydaje się, że poza wspomnianymi wyżej cechami i postulatami, również teologia Żydów mesjańskich mieści się całkowicie w ramach teologii protestanckiej wraz z cechami charakterystycznymi dla ewangelikalizmu.

Wraz z rozwojem ruchu Żydów mesjańskich zaistniało zjawisko szczególnej judaizacji wśród części chrześcijan ewangelikalnych. Zbory Żydów mesjańskich przyjmują na swoich członków także nie-Żydów. W Polsce istnieją również społeczności określające się mianem Żydów mesjańskich, jednakże osoby pochodzenia żydowskiego stanowią w nich zdecydowaną mniejszość. ${ }^{29}$ Zainteresowanie judaizmem wiedzie do zaprowadzania elementów judaistycznej obrzędowości w Kościołach i Zborach ewangelikalnych. Organizowane są przykładowo chrześcijańskie sedery paschalne, które cieszą się bardzo dużym zainteresowaniem. Obrzędy te odbywają się nawet w parafiach Kościoła Ewangelicko-Augsburskiego.

Stosunek ewangelikalnych chrześcijan do judaizmu i Izraela powoduje różne reakcje w świecie żydowskim. Żydzi, a zwłaszcza Państwo Izrael, tak bardzo potrzebują przyjaciół we współczesnym świecie, że z radością witają wsparcie i przyjazne gesty chrześcijan ewangelikalnych. ${ }^{30} \mathrm{Z}$ drugiej strony działalność Żydów mesjańskich

29 Zbór Żydów mesjańskich funkcjonuje od lat przy „Chrześcijańskiej Społeczności”, czyli warszawskim zborze Kościoła Chrystusowego. Większość osób biorących udział w nabożeństwach stanowią nie-Żydzi. Do Kościoła Chrystusowego należy misja „Poślij mnie”, która odpowiada za działania misyjne ukierunkowane judaistycznie na terenie Polski; zob. stronę internetową poslijmnie.pl. Tego rodzaju organizacji jest w Polsce więcej.

30 T. J. Zieliński podaje, że w kwietniu 1998 r. Benjamin Netanyahu powiedział do grupy ewangelikalnych chrześcijan: „Nie mamy większych przyjaciół i sojuszników niż ludzie siedzący na tej sali"; T. J. Z i e 1 i ń s k i, Protestantyzm ewangelikalny, s. 280. Kolejnym przykładem wyjścia naprzeciw chrześcijańskiemu zainteresowaniu Izraelem jest fakt uruchomienia przez grupę wydawniczą Jerusalem Post magazynu przeznaczonego dla chrześcijan ,The Jerusalem Post. Christian Edition”; zob. http:// data.axmag.com/data/VIP/201310/U107603/F245865/FLASH/index.html. 
oraz chrześcijańskich misji wśród Żydów ze zrozumiałych względów oceniana jest przez wyznawców judaizmu negatywnie. Wbrew staraniom Żydów mesjańskich zaprezentowania swojej religii jako judaizmu tylko o specyficznie mesjańskim zabarwieniu, jest to fenomen chrześcijański, a nie żydowski, a przyjmowane przezeń zasady wiary opierają się na protestanckiej dogmatyce. Nie jest to także nowy ruch w obrębie chrześcijaństwa, lecz kolejna odsłona nurtu ewangelikalnego.

Dla wyznawców judaizmu konstytutywne i najistotniejsze dla religijnej tożsamości jest zachowanie przykazań Tory (czy to interpretowanej na sposób ortodoksyjny, czy też na sposób postępowy), dla tzw. Żydów mesjańskich przykazania Tory, ani jej obowiązywanie jako żądania skierowanego do Izraela, nie mają zasadniczego znaczenia, lecz przede wszystkim wiara w Chrystusa jako wcielonego Boga. Żadna ze społeczności tzw. Żydów mesjańskich nie zachowuje przykazań Tory ani nie prowadzi żydowskiego życia religijnego, wprowadza tylko do swojej praktyki religijnej pewne efektowne elementy judaizmu. Uznanie przez chrześcijan Jezusa z Nazaretu za wcielonego Boga i praktyki kierowania do Niego modlitw oraz oddawania Mu boskiej czci nie mogą być w żaden sposób zaakceptowane przez judaizm, ponieważ podważają jego najistotniejszą zasadę i są zakazane w rabinicznej interpretacji Tory. Dlatego że Żydzi mesjańscy przynależą do chrześcijaństwa, a nie do judaizmu, posługiwanie się przez nich (a także przez innych chrześcijan) żydowskimi artefaktami religijnymi, takimi jak kipy, tałesy, mezuzy, a także mniej lub bardziej udane naśladowanie żydowskich świętych obrzędów, wywołuje zrozumiały sprzeciw. Użycie to nie jest prowadzone $\mathrm{w}$ celu instruktażowym $\mathrm{w}$ ramach poznawania innej religii, nie jest ono także przybliżaniem wiernym chrześcijanom religii Jezusa, ponieważ artefakty i obrzędy są najczęściej wzięte ze współczesnego judaizmu, a nie z judaizmu czasów Drugiej Świątyni. Chodzi o użycie religijne, zastosowanie podczas chrześcijańskich obrzędów religijnych i o chrystianizację żydowskich obrzędów i żydowskiej liturgii. Trudno dziwić się, że takie postępowanie jest uwłaczające dla Żydów i obrażające ich w najbardziej wrażliwym 
punkcie. Żydowskie prawo religijne zastrzega sprawowanie obrzędów religijnych dla Żydów, nie-Żydzi są natomiast przez żydowskich teologów zapraszani do realizowania przykazań odnoszących się do relacji międzyludzkich i mających charakter etyczny. Lawrence Kushner pisze: „Czynione zazwyczaj w dobrej wierze zapożyczanie przez chrześcijan żydowskich praktyk religijnych, takich jak kolacja seder czy zapalanie dziewięcioramiennego świecznika chanukowego, jest dla Żydów niezrozumiałe, a nawet obraźliwe. To tak jakby Żydzi powiedzieli: «O tak, kochamy chrześcijaństwo - też sobie robimy taką małą Eucharystię!»" 31

Ewangelikalna sympatia do Izraela nierzadko nie obejmuje rzeczywistego Izraela, ale pewien twór z własnych wyobrażeń religijnych niewiele mający wspólnego z rzeczywistością. Judaizm i Izrael nie pełnią tam autonomicznej roli, ale podporządkowane są chrześcijańskiej dogmatyce, najczęściej dotyczącej eschatologii. ${ }^{32}$ Żydzi stają się więc jednym $\mathrm{z}$ elementów chrześcijańskiego religijnego światopoglądu, pozbawia się ich natomiast prawa do przemawiania własnym głosem.

W kilku słowach podsumowania powtórzyć należy, że ewangelikalizm deklaruje oficjalnie pozytywny stosunek do judaizmu i Izraela, przyznaje trwanie przymierza z Bogiem i jego wybraństwa. Jednocześnie ma duży problem ze zdefiniowaniem tego przymierza i nie jest w stanie pogodzić tego przekonania ze swoją teologią opartą na konwertyzmie i staurocentrycznej chrystologii. Ruch Żydów

31 L. K u s h n e r, Duchowość żydowska. Krótkie wprowadzenie dla chrześcijan, Poznań 2002, s. 96-97.

32 Jak pisze T. J. Zieliński, ,pewna część tego kręgu chrześcijańskiego postrzega dynamikę dziejów ludu żydowskiego jako «małą wskazówkę na zegarze dziejów świata» (...) Rzecznicy tej perspektywy zwykle przyjmują, że powtórne przyjście Jezusa (paruzja) nastąpi fizycznie w Jerozolimie, a apokaliptyczna bitwa Armageddon $(A p 16,16)$ odbędzie się w Izraelu na północny wschód od tego miasta. Dlatego opowiadają się za jak największą koncentracją ludności żydowskiej w Ziemi Świętej oraz politycznym i militarnym wspieraniem państwa żydowskiego, by mogło ono czynnie włączyć się w eschatyczny konflikt"; T. J. Z i e li ń s k i, Protestantyzm ewangelikalny, s. 281. 
mesjańskich jest próbą prowadzenia misji wśród Żydów w nowy sposób, lecz wpisuje się znakomicie w protestantyzm ewangelikalny. Teologiczne poglądy przedstawicieli ruchu Żydów mesjańskich nie są na tyle odmienne od teologii protestanckiej, aby można było mówić o odrębnym prądzie teologicznym. Różnice i odmienności są drugorzędne. Dotyczą one hebraizacji terminologii teologicznej i biblijnej i położenia większego nacisku na chrystologiczną interpretację tekstów Starego Testamentu, mających dowodzić mesjańskiej i boskiej godności Jezusa z Nazaretu. Propozycja zgłoszona przez Davida H. Sterna stworzenia żydowsko-chrześcijańskiej Tory wydaje się raczej nośnym hasłem niż konsekwentnie zarysowanym programem teologicznym. Nie tylko ruch Żydów mesjańskich, ale i ewangelikalizm nie jest teologicznie gotowy do prowadzenia dialogu międzyreligijnego z wyznawcami judaizmu opartego na wzajemnym szacunku i uznaniu prawomocności religii partnera. 